\title{
Perineural Cell
}

National Cancer Institute

\section{Source}

National Cancer Institute. Perineural Cell. NCI Thesaurus. Code C41416.

A cell surrounding a neuron. 